\title{
THE RELATIONSHIP BETWEEN MEDICAL MALPRACTICE AND QUALITY OF CARE $\dagger$
}

\author{
ROBERT H. BROOK, * RUDOLF L. BRUTOCO, ** AND \\ KATHLEEN N. WILLIAMS****
}

\section{INTRODUCTION}

Medical inalpractice claims are increasing at a rate of about ten percent per year. ${ }^{1}$ Seven chairmen of neurosurgery departments in leading New York hospitals have a combined total of twenty-five inalpractice suits filed against then, seeking an aggregate total of $\$ 6.3$ million. ${ }^{2}$ In 1960, total inalpractice premiums in the United States were $\$ 60$ million; by 1975 , the total will be about $\$ 1$ billion. ${ }^{3}$ Many insurance companies have stopped providing professional liability coverage and soine physicians have been tenuporarily unable to obtain inalpractice insurance at any price.

California, although perhaps at the frontier of the inedical nralpractice issue, is not atypical. The number of claims per 100 physician policy years there has increased from about twelve in 1968-69 to about twenty-five in 1975.4 In 1974-75, six jury awards in California were for over a million dollars each; in the state's entire history, there have been only sixteen awards of over a million dollars each. $^{5}$ Rates for inalpractice insurance increased by 400 percent

* M.D., Sc. D.; Assistant Professor of Medicine, UCLA; Senior Staff Health Services Researcher, The Rand Corporation, Santa Monica, Calif.

** Schools of Medicine and Public Health, UCLA; Consultant, The Rand Corporation, Santa Monica, Calif.

*** M.A.; Graduate Fellow, The Rand Corporation, Santa Monica, Calif.

$\dagger$ The research reported in this Article was performed pursuant to a grant from the U.S. Department of Health, Educatiou and Welfare, Washington, D.C. The opmions and conclusions expressed herein are solely those of the authors, and should not be coustrued as representing the opinious or pohicy of any ageucy of the United States Government.

1. Liability Versus Protection, MED. Econ., Oct. 29, 1973, at 93.

2. Evidence Suggests Causes of Professional Liability Problem, 2 COMMENTary, No. 5, at 2 (Med. Liability Comm'n, July 1975).

3. Now Doctors Charge Insurers With Malpractice, Business WeEk, Aug. 4, 1975, at 40; cf. Stevcs, Medical Malpractice In Perspective, 28 CPCU ANNAIs 209, 215 (1975).

4. State by State Survey Finds Professional Liability Woes in Many Regions, AM. MED. NEws, Feb. 24, 1975, at 9.

5. Id. 
between 1968 and 1970, and in Southern California, physicians in highrisk specialties such as orthopedics or neurosurgery inay have premiums in the $\$ 30,000$ range. ${ }^{\circ}$ In other states, such as Ohio, rate increases as high as 750 percent in one year have been requested. ${ }^{7}$ Physicians, in turn, are turning the inalpractice issue back on itself. Suits have been filed against insurance coinpanies charging that they are conspiring to limit the availability of malpractice insurance, thus making it easier for these companies to sell policies which contain provisions favorable to them. ${ }^{8}$ A Florida orthopedic surgeon has filed a $\$ 3$ million suit against two former patients and their attorneys, who had previously sued him for alleged malpractice. ${ }^{9}$ Physicians have also begun to strike for legislative intervention to solve the malpractice crisis. ${ }^{10}$ These strikes have resulted in ecowomic chaos, if not potential ruin, for some hospitals, and at least temporary dislocations in the usual pattern of obtaining medical care for soine people.

In response to these pressures from all sides, legislation which would affect some aspect of malpractice has either been introduced in the legislature or is im preparation in all but three states-Virginia, Wyoming, and Mississippi. ${ }^{11}$ In addition, four federal bills are pending for consideration by the Congress. ${ }^{12}$ Much of the proposed legislation would radically alter the malpractice system, the principle elements of which include: (1) patient responsibility to recognize when an injury has occurred; (2) patient responsibility to deternine whether that injury might be due to negligence; (3) patient responsibility to approach the legal system to determine if he should receive a settlement for the injury which has occurred; and (4) resolution of the claim through the tort system, which pits the physician and his insurance company against the patient and his lawyer.

Some of the arguments for or against changes in the malpractice system are concerned with the impact of the present and future systems

\section{See note 58 infra.}

7. Curran, Malpractice Insurance: A Genuine National Crisis, 292 New ENG. J. MED. 1223 (1975).

8. Now Doctors Charge Insurers With Malpractice, supra note 3, at 40.

9. Rosenberg, He Sued His Malpractice Accusers Right Back-For $\$ 3,000,000$, Med. ECoN. Dec. 8, 1975, at 69.

10. L.A. Times, Jan. 9, 1976, § 1, at 1, col. 2; id., Dec. 30, 1975, $\$ 1$, at 1, col. 2; N.Y. Times, June 15, 1975, \& 4, at 6, col. 1; id. June 2, 1975, at 1, col. 1; id., May 4, 1975, \& 4, at 3, col. 2. The Anerican Medical Association House of Delegates officially approved the use of "slowdowns." Altman, A.M.A. Backs Doctors Curbing Service, N.Y. Times, June 18, 1975, at 81, col. 1.

11. See note 93 infra.

12. See note 118 infra. 
on the quality of medical care provided, and this Article is addressed to that issue. Specifically, the Article is divided into three parts: (1) consideration of quality-of-care constructs, including the art-of-care, technical care, quality-of-care assessment, and quality-assurance programs; (2) the relationship of malpractice to quality of care, with emphasis on imsurance premiums and on availability of physicians; and (3) the development of policy and research suggestions for understanding and/or altering the present malpractice systein.

\section{QUALITY-OF-CARE CONSTRUCTS}

Interest in measuring the quality of medical care and then using the results of this assessment to improve the quality of care delivered is at least 100 years old. Florence Nightingale studied the medical facilities available to the British Army during the Crimean War ${ }^{13}$ and developed a simple reporting system to highlight the unsafe conditions which existed in army field lospitals. Her work indicated that clianges in samitary conditions in these hospitals could produce dramatic reductions in case-fatality rates. In order to promote changes, she developed widely published charts which graphically depicted the high death rate of soldiers in these liospitals.

In 1908, Ernest W. H. Groves, a surgeon at the Bristol General Hospital, issued a plea for the uniform registration of results of operations. ${ }^{14}$ In pursuit of this goal, he conducted a survey of the fifty British hospitals with over 200 beds, receiving replies from twentyseven hospitals. Results of the survey showed that there was a forty-four percent operative mortality from radical operations for malignant diseases of the stomach, a twenty-four percent mortality from prostatectomies, and a nine percent inortality from appendectomies. The personnel in the hospitals which responded to his questionnaire considered it desirable and feasible to institute a system for routinely recording results of operations, but little came of this sentiment. ${ }^{15}$

A few years later in the Umited States, Ernest A. Codinan, a surgeon at the Massachusetts General Hospital, attempted to determine

13. F. Nightingale, Proposal for Improved Statistics of Surgical Operations, in Notes on Hospitals 171 (3d ed. 1863).

14. Groves, A Plea for Uniform Registration of Operation Results, 2 BRTr. MED. J. 1008, 1008-09 (1908). The basis for Groves's plea was:

If . . a surgeon makes a specialty of some disease or operation and tabulates all his own results, or another by chance has some notable successes and records them, or the author of a textbook collects published records of various writers and summarizes them, is it not obvious that such collection of figures will represent the best and not the average results? Id. at 1008 .

15. Id. 
whether patients were well treated by instituting a follow-up system at the hospital. ${ }^{16}$ The objective of this system was to raise his own level of performance by examining all the patients on whom he had operated, one year after their operations. After being thoroughly frustrated in these efforts, he resigned his position as a professor of surgery and started his own hospital in which he instituted a follow-up system. Each patient on whom he had operated was recalled a year later and his health reassessed in terms of: the original objectives of the initial operation. From this assessment, Codman determined whether his original diagnosis was correct, whether his operation was a technical success, whether the patient benefited from the operation, and whether he had produced untoward iatrogenic effect by operating on this patient. ${ }^{17}$

Despite this century-old interest in quality of care, there is little agreement on a precise definition of quality of care; how to measure it; what, if any, deficiencies exist in the care provided; and how, if necessary, to iniprove it. The quality-of-care problein takes on a special significance in the midst of the current medical malpractice crisis. Yet despite the absence of an agreennent on any precise definition of quality of care, its measurement, and low to inprove it, certain generic principles are relevant to the discussion which will follow.

\section{Art-of-Care}

Any definition of quality of care must contain at least two constructs: the art-of-care provided and the technical aspect of the care provided. The art-of-care refers to what Professor Donabedian ${ }^{18}$ would call the management of the social, economic, and cultural aspects of the plrysician-patient relationship. Increasing the art-of-care would result in: (1) adoption by the patient of a life style conducive to

16. Codman, The Product of a Hospital, 18 SURGERY, GYNECOLOGY \& OBSTETrics 491 (1914). Expressing his concern over the quality of care, Codman lamented:

One might say that the instruction of the students is irrespective of the results to the patients, but let us suppose, in surgery, for example, that all the operations which have been watched by these students have been misdirected efforts at the cure of disease, and the students have learned to do something which is not worth while and does not really improve the patient. The product of the hospital in this case, eveu as regards student instruction, would be nil-even worse than nil. We are, therefore, referred again to the classification of disease and the results to the patients, because a student would naturally wish to receive his instruction at a hospital where the treatment was shown to be of benefit to the patient. We may, then, say that the product of the hospital in medical education, bike the product in the number of cases treated, depends on whether or not the cases are well treated . . . I Id. at 492.

17. E. Codman, A Study In Hospital Efficiency: The First five Years (1916).

18. Donabedian, Promoting Quality Through Evaluating the Process of Patient Care, 6 Med. CARE 181 (1968). 
longevity; (2) increased compliance by the patient with regimens for controlling asymptomatic or mildly symptomatic chronic disease; (3) willingness on the part of the patient to discuss "sensitive" symptoms and health problems with the physician; and (4) utilization of health services in a timely manner so that symptoms or problems would be dealt with at a stage when they can be cured or ameliorated.

Valid measures for assessing the art-of-care are just now being developed. ${ }^{19}$ Thus, there is a dearth of information on how the artof-care varies as a function of physician or medical care system characteristics. For instance, the question of whether an internist or family practitioner provides a higher level of art-of-care cannot be answered by available infornation. Likewise, no information is available to answer the question of whether the physician-patient relationship has deteriorated in the last decade. ${ }^{20}$ Clearly, the belief that malpractice suits have increased because the doctor-patient relationship has deteriorated can be neither confirmed nor demied by objective information.

\section{Technical Care}

Measurement of the technical aspect of care concerns whether (1) the diagnosis was adequately established; (2) therapy was appropriate; (3) diagnostic and therapeutic procedures were applied in an efficient manner; (4) medical technology was reasonably exploited; and (5) appropriate professional measures and facilities were used. Numerous research or quasi-research studies have assessed or evaluated the techmical aspects of care; ${ }^{21}$ niost of these liave reported substantial deficiencies in the care provided. Examples imclude the following cases: anemia was not recognized or treated in forty-five percent of the anemic children being cared for at a Children and Youth project which was providing "comprehensive" care; one half of these children were anemic at the end of the study. ${ }^{22}$ One eighth of all hospital admissions of Teamsters Union family members in New York City were considered medically unnecessary, and two fifths of those admitted received only

19. See Ware \& Snyder, Dimensions of Patient Attitudes Regarding Doctors and Medical Care Services, 13 Med. CARE 669, 670 (1975).

20. But cf. Mechanic, Some Social Aspects of the Medical Malpractice Dilemma, 1975 DUKE L.J. 1179, 1183-84.

21. See, e.g., Brook, Quality of CARE AsSessment: A Comparison of Fivg METHODS OF PEER REVIEW (1973) (DHEW Publication No. HRA-74-3100).

22. Starfield \& Sheff, Effectiveness of Pediatric Care: The Relationship Between Processes and Outcome, 49 Pediatrics 547 (1972). 
fair or poor care. ${ }^{23}$ Only one fourth of patients with severe gastrointestinal symptoms who presented themselves to the emergency rooin of either a university ${ }^{24}$ or a city hospital ${ }^{25}$ were judged to have received a level of care which met even minimum standards. One third of North Carolina's general practitioners were found to be delivering a poor or marginal level of care. ${ }^{26}$ Fifty-one percent of a sample of Ontario physicians and twenty-six percent of a sample of Nova Scotia physicians were found to be practicing medicine of satisfactory quality. ${ }^{27}$ Examination of the quality of care given by Hawaiian physicians demonstrated deficiencies in both the hospital and ambulatory settings; provision of good care would have required increasing the taking and recording of medical histories and physical examinations, performing more laboratory tests, and providing more follow-up care. ${ }^{28}$

Technical care, therefore, has been shown to be deficient regardless of how it is paid for, who provides it, or in what setting it is provided. In the absence of adequate mechanisms and finances to assess and improve the quality of care provided, this situation should not be unexpected.

\section{Quality-of-Care Assessment}

Quality-of-care assessment is hampered by methodologies and problems of real policy relevance. Quality of care can be assessed by three different variables: structural, process, or outcome. Structural variables are innate characteristics of facilities and physicians, such as whether a poison chart is posted in an emergency room, or the age

23. R. Trussell, M. Morehead \& J. Ehrlich, The Quantity, Quality and Costs of Medical and hospital Care Secured by a Sample of TEamster Fammies in the NeW YoRK AREA 21, 25 (1962).

24. Brook, Berg \& Schechter, Effectiveness of Non-emergency Care Via an Emergency Room: A Study of 166 Patients with Gastro-intestinal Symptoms, 78 ANNaIs of INTERNAL MeD. 333, 337 (1973).

25. Brook \& Stevenson, Effectiveness of Patient Care in an Emergency Room, 283 New ENG. J. Med. 904, 907 (1970).

26. Peterson, Andrews \& Spain, An Analytical Study of North Carolina General Practice 1953-1954 (pt. II), 31 J. MED. Educ. 1 (No. 12 1956).

27. Clute, The Quality of General Practice, in Generad PractirIoner 262-340 (1963).

28. B. Payne \& T. Lyons, Method of Evaluating and Improving Personal Medical Care Qualtix: Office Care Study (Am. Hosp. Ass'n, In Press); B. Payne \& T. Lyons, Method of Bvaluating and Improving Personal Medical Care Qualtiy: Bpisode of Illness Study (Am. Hosp. Ass'n, In Press). Simple calculations on data from these studies suggest that the number of ambulatory procedures might need to be doubled and the number of inpatient procedures increased by one half to meet reasonable standards of good care. 
or board certification status of the physician. Process variables refer to what a physician or other health provider does to or for a patient, such as whether a cardiogram is ordered for a patient with crushing chest pain. Outcome variables are those concerned with what happens to a patient and are measured by mortality, morbidity, disability, and psychosocial functioning.

The purpose of the medical care system is to improve the health of people, a goal which is not necessarily synonymous with either raising the qualifications of health care providers or increasing the number of services provided. The most valid assessment of quality of care is gained through outcome information. Regulation of the medical care systein, however, depends upon information which can be collected inexpensively; to date, this has meant relying on structural and process information which can be obtained from routine reports, insurance claims forms, or the inedical record. Collection of outcome information usually requires arranging for a follow-up interview with the patient, an extremely expensive procedure. Unfortunately, many structural and process items used to assess care have been shown not to be valid, i.e. not related to improvement in patient health. For example, physicians who are specialists, who graduated high in their medical school classes, who attend continuing education courses, or who subscribe to (and read) journals are not necessarily better physicians. ${ }^{29}$ Coinprehensive care clinics do not necessarily provide better techurical care than do hospital outpatient clinics. ${ }^{30}$ The only two structural variables which consistently seem to relate to better quality of care are whether the physician is a "modal" specialist and whether he is young. ${ }^{31}$ In some, but not all, studies, board-certified physicians performed better than their noncertified colleagues. ${ }^{32}$

Similarly, much of what is known about which processes of care are related to improved health is based on conventional wisdom, and tests

29. See Peterson, Andrews \& Spain, supra note 26 , at $71,83,88$.

30. Morehead, Donaldson \& Seravalli, Comparisons Between OEO Neighborhood Health Centers and Other Health Care Providers of Ratings of the Quality of Health Care, 61 AM. J. Pub. Health 1294, 1306 (1971).

31. B. Payne \& T. Lyons, Episode of Itlness Studx, supra note 28 . The term "modal specialist" refers to treatment of a patient by a physician who is trained to treat the specific problem the patient has. For example, the modal specialist for a child with a kidney stone is a urologist, and not a family practitioner.

32. See R. Trussell, M. Morehead \& J. Ehrrich, supra note 23 , at $45-46,83$ table 34; B. Payne \& T. Lyons, Episode of Illness Study, supra note 28; R. BRooK \& K. Williams, EfFect of THE New Mexico Peer ReVIew System on Cost aNd QualtTy of Medical Care: A Review of the Impact of the New Mexico Expermmental medical Care Review Organization on Medical Care Delivered to the Medicaid Population, 1971-1973 (Rand Corporation, To Be Published). 
of conventional wisdom sometimes produce disturbing results. For instance, not all women with breast cancer necessarily need a radical mastectomy ${ }^{33}$ treatment of adult onset diabetes with oral hypoglycemic agents probably does more harm than good; ${ }^{34}$ some groups of patients who have acute heart attacks may, on the average, have a higher probability of survival when treated at home than when treated in a inodern coronary care unit; ${ }^{35}$ and many women with varicose veins will obtain an equally acceptable cosmetic result with less morbid complications when treated with a simple outpatient procedure than with the conventional operation which requires hospitalization. ${ }^{36}$ Yet all the more aggressive procedures are still standard accepted therapy, and likely would be the benchmark by which acceptable quality of care would be judged in any national medical care review system.

Regulation on the basis of structural or process information must be done carefully. No matter what variable (structural, process, or outcome) is used in quality assessment, deficiencies in care will be found, but the level of those deficiencies will vary considerably as a function of the assessment method used. ${ }^{37}$ If quality-of-care assessment on the basis of process data differs inarkedly from assessment on the basis of outcome data, acceptance of the former as a basis for taking steps to improve care might lead to large imcreases in the amount of money spent on personal medical care without a corresponding improvement in the health of the American people. ${ }^{38}$

33. See Meier, Statistics and Medical Experimentation, 31 BIometrics 511, 515-16 (1975).

34. The University Group Diabetes Program, A Study of the Effects of Hypoglycemic Agents on Vascular Complications in Patients with Adult Onset Diabetes, 19 DisbeTes Supp. 2 (1970). The UGDP study suggests that the specific hypoglycemic used-tolbutamide-raises the incidence of cardio-vascular illness in diabetic patients. The study, however, did not extend its findings to include other hypoglycemic agents.

35. Mather, Pearson \& Reed, Acute Myocardial Infarction: Home and Hospital Treatment, 3 BRIT. MED. J. 334 (1971).

36. Chant, Jones \& Weddell, Varicose Veins: A Comparison of Surgery and Injection/Compression Sclerotherapy, 2 LANCET 1188 (1972); Piachaud \& Weddell, Cost of Treating Varicose Veins, 2 LANCET 1191 (1972).

37. For a study demonstrating this variance, see Brook, supra note 21 . Using process and outcoine data, Brook assessed the quality of care delivered to 296 patients with either an ulcer in the stomaclı or duodenum, hypertension, or a urinary tract infection. Process assessment indicated that twenty-three percent of patients received acceptable care, but outcome assessment indicated that sixty-three percent of patients received acceptable care. Id. at iin. The truth undoubtedly lies somewhere in bctween, and the decision of how care should be improved is dependent upon which number is accepted. Id.

38. See id, at 57. 


\section{Quality-Assurance Programs}

Attempts to assess quality of care have been confined largely to research endeavors. In the last two years, however, two major qualityassurance programs have been developed. ${ }^{39}$ The first is the Professional Standards Review Organization (PSRO) program, which has been established to review and improve the quality and efficiency of hospital care given to Medicare and Medicaid recipients. ${ }^{40}$ The second is the Physician Evaluation Performance (PEP) program of the Joint Commission on the Accreditation of Hospitals, which requires the performance of process and outcome audits for the maintenance of hospital accreditation. ${ }^{41}$

Both programs contain similar features: (1) review of hospital care only; (2) selection of a few diagnostic categories for audit; (3) local determination by physicians of the diagnostic categories for audit and of the criteria and standards against which care will be audited; (4) reaudit to determine if deficiencies have been corrected; and (5) reporting of results to an external body-the federal government or the Joint Commission. Both PSRO and PEP have virtually excluded the public from any real role in quality assurance. For instance, in order to implement the PSRO program, the United States has been divided into 203 areas. In each of these areas a group composed solely of physicians has the right to organize the PSRO, with the public excluded from any role at the local level. Determination of whether local PSROs and PEPs work is left mostly to imagination, since the system by which PSROs and PEPs are evaluated is weak. ${ }^{42}$ It is too early to tell whether either one or both of these programs will contribute to improving the health of the American people.

\section{Relationship of MaLPRACTICE TO QUALity of CARE}

Facts about the operation of the present medical malpractice system are sparse. Those that both relate to the quality-of-care issue and are consistent among observers of the malpractice systein are even more sparse. Nevertheless, certaim facts which are germane to an

39. Because of their very recent implementation, it is of course too early to predict whether either one or both of these programs will contribute to improving the health of the American people.

40. 42 U.S.C. $\S 1320$ C-1 to C-19 (Supp. III 1973). See Office of Professional StaNdards ReVIEW, PSRO Program MaNual (1974) (HEW Publication).

41. See C. Jacobs \& N. Jacobs, The PEP Primer: The JCAH Performance Evaluation Procedure for Auditing and Improving Physician Care (1974).

42. R. Brook \& A. Avery, Quality Assurance Mechanisms IN the United States: From There To Where? 15 (Rand Corp. Paper Series, P-5520, Oct., 1975). 
examination of the relationship between malpractice and the quality of medical care can be identified.

Malpractice premiums have increased dramatically in the last few years, and even larger increases have been proposed. ${ }^{43}$ This increase in premiums has paralleled a rise in the number of malpractice claims, and there are predictions that every practicing physician will be sued at least once in his lifetime. ${ }^{44}$ Premiums vary substantially by area of the country, ${ }^{45}$ and are set principally according to the amount and type of surgery a physician does. ${ }^{46}$ Certain surgical specialists and anesthesiologists pay much higher premiums than internists or pediatricians, and are the targets of many more malpractice claims. ${ }^{47}$

Malpractice premiums are, in general, not experience-rated at the individual physician level. ${ }^{48}$ A physician who practices part-time is likely to have a premium similar to one who practices full-time; a pediatrician who sees 100 patients per day probably will have the same premium as one who sees ten patients per day; and a physician with a malpractice claim pending will have the same premium as one who

43. In Ohio, increases of 750 percent in a year have been proposed. Curran, supra note 7 , at 1223-24.

44. Liability Versus Protection, Med. EcoN., Oct. 29, 1973, at 93.

45. State by State Survey, supra note 4. See Steves, A Proposal to Improve the Cost to Benefit Relationships in the Professional Liability Insurance System, 1975 DUKE L.J. $1305,1319$.

46. A general practitioner, pediatrician, or internist who does not perform even minor surgery may have a premium one-seventh that charged an orthopedic surgeon. Kendall \& Haldi, The Medical Malpractice Insurance Market, in MEdiCAL MaLPRACTICE REPORT Appendix 494, 505. Specialists in the areas of orthopedic surgery, neurosurgery, anesthesiology, and obstetrics-gynecology have the highest premiums. Cf. Steves, supra note 45 , at $1316-17 \& \mathrm{n} .65$.

47. A survey of medical malpractice incidents in Maryland during the decade from 1960 to 1970 revealed that slightly more than half of the malpractice claims were associated with four high-risk specialties: general surgery, eighty-six claims; obstetrics-gynecology, sixty-eight claims; anesthesiology, thirty-six claims; and thoracic surgery, nine claims. These specialists, however, coinprised only one fourth of the physician membership insured under the program being studied. Evans, Hemelt \& Olsson, $A$ Survey of Professional Liability Incidence in Maryland, in Medical Malpractice Report Appendix 623; Pabst, Comments on the Maryland Professional Liability Survey, in MeDICAI Malpractice Report Appendix 632.

An examination of all claims closed throughout the United States in 1970 substantiated these findings concerning the skewed distribution of malpractice claims. Rudov, Myers \& Mirabella, Medical Malpractice Insurance Claims Files Closed in 1970, in MeDICAI MALPRACTICE REPORT Appendix 1. For example, anesthesiologists produced 7.9 percent of the malpractice claims, but represent 3.6 percent of the U.S. physician pool; orthopedic surgeons produced 8.8 percent of the claims, but represent only 3.2 percent of the pool. Similar figures for internists are 6.9 and 14.0 percent, respectively, and for pediatricians 2.3 and 6.0 percent. Id. at 16.

48. See Kendall \& Haldi, supra note 46 , at $533-34$. 
does not. Further, the likelihood of a physician being sued does not vary markedly with personal or professional characteristics, with the exceptions of specialty and area of the country in which he practices. For instance, age, board certification, urban versus rural practice, and foreign medical training seem to have little bearing on the frequency of involvement in litigation. ${ }^{49}$ It also appears that the likelihood of a physician being sued more than once is related as much to elrance as to his being a poor physician. ${ }^{50}$ Finally, the probability of being sued varies with the practice site in which care was given: a higher percentage of malpractice meidents occurs within a hospital treatment setting than during office visits. ${ }^{.1}$

49. Examination of malpractice claims closed in 1970 indicated that sixty percent of the physicians involved in a claim were board-certified; the age distribution of physicians who were sued did not differ from that of the U.S. physician population as a whole. Rudov, Myers \& Mirabella, supra note 47, at 16-17.

Examination of 3,166 physicians insured under the Maryland Med-Chi program from 1960 to 1970 indicated that of the $\mathbf{3 2 2}$ physicians sued, forty-nine percent were board-certified. Board-certified physicians were just as likely to be sued multiple times as were nonboard-certified physicians. Furthermore, urban physicians were only slightly more likely to be sued than were rural physicians. Fifteen percent of the claims were against graduates of foreign, non-English-speaking medical schools, but nineteen percent of the physicians had been educated in such schools. Thus, physicians who were older, not board-certified, or foreign trained-characteristics which have been associated in some studies with the provision of a lower level of quality of care-do not appear to account for a larger proportion of malpractice claims than would be expected by chance alone. Evans, Hemelt \& Olsson, supra note 47, at 626-27; Pabst, supra note 47, at 634 . This conclusion is weakened somewhat by the manner in which the data from the studies quoted above were analyzed. When the relationship between age or board certification and the number of inalpractice claims was determined, specialty was not taken into account. Specialty is highly correlated with the number of malpractice claims. If specialty also has a high correlation with age or board certification status, then a significant relationship between age or board certification status and the number of malpractice claims could have been missed.

50. Of the 3,166 physicians insured under the Med-Chi program in Maryland from 1960 to $1970,2,844$ (ninety percent) were not sued; 276 (nine percent) were sued once; and forty-six physicians ( 1.4 percent) were sued more than once each for a total of 105 times. Evans, Hemelt \& Olsson, supra note 47, at 624, 630; see Pabst, supra note 47, at 633-34. Chance would predict that twenty-one physicians would have had more than one claim filed against them. Id. at 634 . If the analysis which produced the number twenty-one had corrected for the variation in suit by specialty, then the deviation from chance would have been even less. Generalization of the results of this one-state study is dangerous, however. More studies are required before definitive conclusions can be drawn.

51. Seventy percent of the malpractice incidents in Maryland between 1960 and 1970 occurred in hospitals, with fourteen percent occurring in emergency rooms, and twenty-nine percent took place in physicians' offices. Evans, Hemelt \& Olsson, supra note 47 at 629-30. Hospital accreditation did not protect the hospital from being sued, since ninety-one percent of the hospitals which settled a malpractice claim in 1970 were JCAH-accredited. Rudov, Myers \& Mirabella, supra note 47, at 17. 

physician-patient relationship. Before discussing each proposed effect in detail, however, it is necessary to place the whole issue in some historical perspective.

Forty years ago, the primary function of the medical care system was the compassionate caring for patients. Malpractice resulting from an imjury caused by improper therapy was almost an impossibility, since most therapies were placebos and capable neither of alleviating a disease nor of causing harm. Today, due to advances in the biomedical sciences, another function of medical care must also be considered: efficient dehivery to the entire population of efficacious inedical services that result in cure or control of disease and maintenance or improvement of health. Unfortunately, new therapies-antibiotics, intensive care units, radical surgical procedures, anti-neoplastic drugs-which do improve the health of the American people are also capable of producing serious iatrogenic disease. The effectiveness of these therapies is determined in part by the methods and nranner by which they are applied, in short, by the level of quality of care. The apparently paradoxical situation which obtains today-nanrely, improvement in the health of the American people due to better inedical care accompanied by an increase in inalpractice claims-is not too difficult to explain: inodern niedicine has increased the physician's chance of doing harm, and the probabilistic nature of inedical treatment alone would suggest that malpractice clains would dramatically increase. Variation in physician performance or choice of therapy, which in 1935 was relatively meaningless, today can have serious consequences in terms of patient well-being. This variation, coupled with the rising public expectation of increased longevity fostered by the bionedical revolution, renders the health care atmosphere even more conducive to the filing of nralpractice claims.

Given this historical relationship between quality of care and the nralpractice issue, the central question of this Article can be posed. In the absence of the present restitution system for inedical nialpractice, would the quality of medical care and (thereby) the health level of the American people increase niore or less than it would if the present malpractice syste1n were kept in place? A direct and simple answer to this question is impossible, but approximations can be obtained by looking at possible effects of the malpractice system on quality.

\section{Malpractice Premiums and Availability of Physicians}

Given both that the amount of malpractice premiums will continue to rise dramatically and that differentials in presmums will continue to 
occur as a function of physician characteristics, several major system effects might be hypothesized:

1. Decrease in the number of applicants to medical school;

2. Decrease in the number of physicians who specialize in high-risk specialties (e.g., orthopedics);

3. Migration of physicians from areas in the country with high premiums to those with low premiums;

4. Decrease in the number of part-time practicing physicians;

5. Decreases im the performance of surgery or special procedures;

6. Increase in the cost of care;

7. Decrease in the number of young physicians who go directly from training into solo fee-for-service practice; and

8. Increase in physician slowdowns or strikes which will either temporarily or permanently make medical care unavailable.

Each of these hypothetical effects merits some comment.

Application Rate to Medical School. In the near future, primary care physicians in private fee-for-service practice may be paying $\$ 5,000$ to $\$ 10,000$ for malpractice insurance; this would be the lower end of the premium scale. It is unlikely that this premium level, in and of itself, would cause the number of applicants to medical school to drop. ${ }^{55}$ Whether some or many students enter medical school for economic reasons is debatable. Not debatable, however, is the fact that these "high" premiums on the average represent a very small percentage (five to ten percent) of the physician's gross salary. ${ }^{56}$ On the whole, physicians will remain at the top of the economic ladder, regardless of the level of malpractice premiums. During hard economic times, the M.D. degree is the only degree which guarantees job stability; this fact alone will continue to lead a large excess of highly qualified apphicants to medical school. High malpractice premiums (at least at the levels

55. The number of applicants for admission to the 1974-75 term in United States medical schools was 42,624 , an increase of 2,118 over the previous year. Crowley (ed.), Medical Education in the United States 1974-75, 234 J.A.M.A. 1333, 1337 table 8 (1975). The number of students applying has increased 122 percent in the last ten years, $i d$. at 1336, although the most recent increase is not so large as the previous year's gain of 4,371 applicants, $i d$. at 1337 table 8.

56. The average gross income for all physicians during 1973 has been estimated at almost $\$ 84,000$. Center for Hearth Services Research and DeVtelopment, AM. Med. Ass'N, ProfiLe of Medical Practice 195 table 66, and 204 table 75 (1974). Net income for the same period was estimated at approximately $\$ 50,000$. Id. at 195 table 66. The estimates were based on approximately 3,000 observations. Average net income was based only on those physicians reporting a profit. 
now being proposed in Southern California) will not cause or aggravate a "physician shortage," if such a phenomenon indeed exists. ${ }^{67}$

Training of Physicians in High-risk Specialties. In Southern California, by 1976, the premium differential between a surgeon and an internist may be $\$ 30,000 .{ }^{58}$ One might argue that this discrepancy would lead to the training of fewer medical school graduates as surgeons, but there is no evidence that this outcome would occur. If it did, it would be socially beneficial. In this country many surgical procedures are performed unnecessarily, and the amount of surgery perforned in any geographic area is related to the number of surgeons in that area. ${ }^{59}$ On the other hand, the number of physicians willing to give first contact primary or family care is in short supply. ${ }^{60}$ Moreover, the differential in income between surgeon and primary care physician is usually greater than the differential in malpractice premiums, ${ }^{61}$ and for those physicians who choose to specialize in surgery for purely economic reasons, the economic rationale remains. The differential in malpractice claims creates an incentive in the right direction (i.e. away from surgery), but that incentive is not strong enough to reduce the number of physicians who are being trained in oversupphed specialties.

Physician Migration. Other things being equal, differentials in imsurance premiums by geographic area could have an effect on quality by causing physician migration from areas of excess physician supply to those which are undersupphied or vice versa. The net effect of such migration is not likely to be observed, however, because of the large size of premiuin areas ${ }^{62}$ and the difficulty of taking account of all other

57. To the extent that physicians are able to pass on the high cost of insurance to patients, the impact on entry into the profession would, of course, be even smaller.

58. The Insurance Services Office rates for California would require a premium payment of $\$ 6,074$ by an internist who performs no surgery for $\$ 100,000 / 300,000$ policy limits. The same coverage for certain surgeons-gynecology, hand, head and ueck, plastic-would cost $\$ 37,066$, according to the ISO ratings. INSURANCE SERVICES OFFICE, Physicians, Surgeons and Dentists Professional Liability Manual (Jan. 1, 1976, Revision) (California P.S. \& D. Rates, Seventh Reprint).

59. See Bunker, Surgical Manpower: A Comparison of Operations in the United States and in England and Wales, 282 NEw ENG. J. MED. 135 (1970); Lewis, Variations in the Incidence of Surgery, 281 NEW ENG. J. MED. 880 (1969).

60. But cf. Crowley, supra note 55, at 1365-66; Wall Street J., Oct. 31, 1975, at 1, col. 1 .

61. The average gross income for surgeons during 1973 has been estimated at approximately $\$ 97,000$, CENTER FOR HeALTH SERvices, supra note 56, at 191 Table 62, and 201 Table 72, some $\$ 18,000$ more than the estimated 1973 gross income of the general practitioner, $i d$.

62. In California, for example, the ISO rates apply to the entire state, with no geographic differentiatiou. Insurance SERVCes OFFICE, supra note 58 . Virginia, by con- 
factors. A doctor practicing in an inner city area where there is an undersupply of physicians, for example, is likely to pay the same malpractice premium as one who practices in the oversupplied suburbs of the same city, ${ }^{63}$ meaning that little incentive exists for him to remain in the inner city and implying that quality might well suffer in that situation. Even in the instance of a premium differential favoring the mner city, the motivation for leaving may be so strong as to outweigh the relatively trivial incentive (for staying) of lower malpractice imsurance costs.

Discouragement of Part-Time Practice. Malpractice premiums that are not adjusted to reflect decreased risk exposure in part-time practice could force many part-time physicians out of practice, and thus decrease the availability of care. Insofar as these pliysicians have characteristics that are associated with being less technically competent, such as being older or smiply not doing enough procedures to remain competent, then their removal from practice would raise the level of care provided. Unfortunately, the characteristics of physicians who choose to work part-time has not been systematically documented. Many physicians may steadily practice until they die at some advanced age; others may practice only sporadically over a large part of their careers. Thus, on average, discouragement of part-time practice may be a positive result of high malpractice premiums. On the other hand, the practice of medicime by competent, young, female plysicians and by academic physicians, many of whoin see patients on a part-time basis, would also be eliminated. Other less discriminatory means should be found to accomplish the objective of removing from practice the incompetent part-time practitioner.

Performance of Surgery by Primary Care Physicians. Premiun differentials between primary care specialists who do not perforin surgery and those who do are large. For instance, in 1976 the general practitioner in Southern Califorina who does not do surgery may have a premium of about $\$ 7,000$; one who does may have a premium of about $\$ 21,000$. An internist in the same area may pay about $\$ 5,000$; if he does bronchoscopy, his premium may increase to about $\$ 10,000 .^{04}$

trast, is divided into three rating territories. Bureau of Insurance, STATE Corp. Comm'n (Virginia), Medical Malpractice Insurance IN VIRginia: The SCope aNd Severtiy of the Problem and Altrernattve Solutions 13 (1975).

63. See, e.g., id. (Nov. 1, 1975, Revision) (New York P.S. \& D. Rates, Third Reprint) (indicating that ISO rates for New York City and suburban Nassau County are identical).

64. The figures in the text are based on personal communications between the authors and insurance officials in California. The nost recent published ratings of the 
Since general practitioners do surgery less frequently than surgeons, this premium disparity could make surgery by general practitioners unprofitable. To make it profitable, practitioners could choose to increase either the amount of surgery they do or the prices they charge. But the surgery market in many areas is becoming saturated, and prices for surgery are likely to be fixed by surgeons and fiscal intermediaries. It is improbable, then, that general practitioners will be able to increase either the amount or price of their surgery. High malpractice premiums thus may increase the likelihood that surgery will be done by surgeons instead of general practitioners. If surgery performed by family practitioners is of poorer quality than that performed by surgeons (this is the accepted belief), then the quality of care will rise as general practitioners are drawn out of the surgical market.

The performance of special procedures is another matter. A specialist in pulmonary disease may be called upon to do only about thirty bronchoscopies a year. If he receives $\$ 200$ per bronchoscopy, then his gross receipts would be $\$ 6,000$. His net receipts would be less than the additional malpractice premium he inust pay. ${ }^{65}$ The incentive would be either to do inore-presumably unnecessary-bronchoscopies, or to stop doing them. Either result is bad. In the first case, patients will be subjected unnecessarily to risky procedures, and in the latter a necessary procedure may become relatively unavailable, at least in some communities or facilities.

Cost of Care. Physicians faced with rising inalpractice premiums will likely try to pass that cost on to their patients. A primary care physician seeing twenty patients a day for 200 days per year has 4,000 patient visits. If his premium increases $\$ 5,000$ for that year, he inay well increase his office visit by $\$ 1$. This is not an insignificant increase. Where groups of patients such as the poor who are eligible for Medicaid are involved, the desire on the part of the physician to raise fees may be particularly burdensoine, for the reason that fee schedules are deter-

Insurance Services Office indicate that a Southern California general practitioner who performs no surgery would pay a $\$ 6,074$ annual premium in 1976 for $\$ 100,000 / 300,000$ inalpractice coverage, plus additional charges for corporate or partnership liability or employment status. A general practitioner performing certain ininor procedures-including angiography, arteriography, catheterization, and needle biopsy-would pay $\$ 18,216$. The annual premium for au internist who does not perform surgical procedures also would be $\$ 6,074$ for $\$ 100,000 / 300,000$ coverage, while the internist who does minor surgery would pay $\$ 11,121$ for the same protection. InsURANCE SERVICES OFFICE, supra note 58. The ISO ratings, of course, are not binding on insurance companies, which must seek state approval for rates.

65 . The added premium of $\$ 5,000$, see note 64 supra and accompanying text, would almost surely exceed the physician's net imcome from $\$ 6,000 \mathrm{~m}$ revenue. 
mined by the state, and not by the physician. Thus, the option of raising fees is not really open to those physicians who practice in areas with large numbers of Medicaid patients. In order to maintain income, those physicians could move to non-Medicaid areas, refuse to take Medicaid patients, see more patients more quickly, imcrease the number of procedures ordered, or raise fees to non-Medicaid patients. All these options would have a deleterious impact on the general level of medical care, by reducing the availability of care to those who need it most or by decreasing the quality of care provided.

Entrance to Solo Practice. High malpractice premiums nay make it harder for young physicians to enter solo fee-for-service practice. Physicians just entering practice might of necessity take positions in group practices or Health Maintenance Organizations (HMOs), even if such positions were not the desired career paths. This result could be viewed as an infringement on the right of a physician to practice medicine in the setting of his choice. At present, there is no evidence to suggest that such a result will occur; nevertheless, if it did, the effect on quality might well be positive. HMOs probably deliver slightly better care, on the average, than does the fee-for-service system. ${ }^{66}$ High malpractice premiums, then, might increase the competitive advantage of HMOs vis-à-vis the fee-for-service system. ${ }^{67}$

Physician Strikes. Finally, the possibility remains that many physicians may stop or curtail providing services in protest against high premiums. ${ }^{68}$ Why physicians have chosen to strike on this issue is unclear. Other equally important cost issues-the rising prices of a hospital day, a medical instrument, or a drug, for example-have been ignored. Physician strikes are likely to generate onerous solutions to the inalpractice crisis, ones requiring greater government regulation of physicians-an outcoine strenuously opposed in the past by organized medicine. ${ }^{69}$ In the short run, the most miportant effect of high mal-

66. See Shapiro, Williams, Yerby, et al., Patterns of Medical Use by the Indigent Aged Under Two Systems of Medical Care, 57 AM. J. PuB. Health 784 (1967); Shapiro, Weiner \& Densen, Comparison of Prematurity and Perinatal Mortality in a General Population and in the Population of a Prepaid Group Practice Medical Care Plan, 48 AM. J. Pub. Health 170 (1958).

67. For a general discussion of HMOs and the malpractice issue, see Bovbjerg, The Medical Malpractice Standard of Care: HMO's and Customary Practice, 1975 DUKE L.J. 1375.

68. See note 10 supra.

69. See, e.g. Association of Am. Physicians \& Surgeons v. Weinberger, 395 F. Supp. 125 (N.D. IIl. 1975), appeal dismissed sub nom. Association of Am. Physicians \& Surgeons v. Mathews, 44 U.S.L.W. 3304 (U.S. Nov. 18, 1975) (unsuccessful constitutional challenge of PSRO legislation). 
practice premiums on quality may be that of causing physician strikes, and consequently making care unavailable to many people in time of need. Long-range solutions to the problems of malpractice need to be designed, but the current crisis must be controlled before it produces substantial harm.

In summary, the direct effects of the increasing cost of malpractice premiums on the quality of national inedical care appear to be minor and somewhat unpredictable. Minor changes that favor improved quality, such as decreasing the number of family practitioners who do surgery or decreasing the number of part-time physicians, may occur. On the other hand, some necessary procedures may become less readily available, and care in general inay become less available to disadvantaged members of society. On balance, changes in current malpractice premium-setting should be formulated without considerimg the potential effects discussed above, because those effects involve fundamental questions about health care delivery which should be addressed on their own merits and because the relationship between higher premiums and those effects is ambiguous at best.

\section{Disciplinary Actions Against Physicians}

A major effect of the current malpractice system on quality of care could occur after the resolution of a malpractice claim, im the form of disciplinary action (or imaction) agaimst either a physician or hospital by some official organization. To examine this contention, three principal factors need to be considered. First, results from analysis of data collected even five years ago inay be irrelevant. Second, contemplated disciplinary actions can vary widely, from loss of license, to suspension or restriction of licensure, to mandated continuing education. Third, no longer will a small subgroup of pliysicians be identified by malpractice insurance claims; thus, disciplining physicians on the basis of their having been sued turns into the inore generic issue of disciplining physicians in general. Data from a study performed in Maryland ${ }^{70}$ indicated that only ten percent of the physicians in that state were sued in the decade from 1960 to 1970 . In the past decade a physician's being sued was a relatively rare event; however, the figure for the decade froin 1975 to 1985 could be fifty to seventy-five percent, a number which could translate a rare event into a cominon phenoinenon.

Disciplinary Measures Past and Present. Disciplinary actions in the past have been few in number, especially at the level of state

70. Evans, Hemelt \& Olsson, supra note 47 , at 623 ; see Pabst, supra note 47 , at 632 . 
licensure boards, where disciplinary measures range from notices of deficiency to license revocations. Prior to this year, physicians in all but three states were licensed for life; five additional states have enacted relicensure provisions during the 1975 legislative sessions. ${ }^{71}$ In the last ten years, 0.66 percent of physicians in the United States liad difficulty with licensing boards; about one half of these pliysicians suffered a major disciplinary action sucli as suspension of licensure. ${ }^{72}$ Most disciplinary actions are for drug or alcohol abuse, unethical behavior, or advertising infractions; only rarely is such a proceeding imitiated on grounds of medical incompetence or malpractice. ${ }^{73}$ Only eighteen states have statutes in effect which specifically mention professional incompetence as justification for removal of a medical licensure. ${ }^{74}$

State medical societies have not been involved significantly in physician discipline. Their actions are not public, and only rarely are the consequences severe; ultimate punishment would be expulsion from the society. As recently as 1965 , only nine state medical societies even specified incompetence as a reason for disciplining a member. ${ }^{75}$ And in 1969, only fourteen physicians in the United States were expelled from their respective state medical societies; another fourteen were suspended. ${ }^{70}$

Extent of Disciplinary Action. In the past ten years, perhaps 0.1 percent of United States physicians have been disciplined on the grounds of medical incompetence. Between 1969 and 1973, seven states with a physician population totaling 23,000 reported no disciplinary action whatsoever. ${ }^{77}$ At the other extrene, California disciplined 0.58 percent of its physicians, while in the five states with the most physicians other than California, 0.11 percent were disciplined. ${ }^{78}$

Estimates of the number of medically imcompetent plysicians

71. See notes $105-08$ infra and accompanying text. See generally Derbyshire, Better Licensure Laws for Better Patient Care, Hosp. PrACrice 152-56, 158, 164 (Sept. 1972).

72. Derbyshire, Medical Ethics and Discipline, 228 J.A.M.A. 59, 61 (1974).

73. Id.

74. Derbyshire, Disciplining the Incompetent Physician, Hosp. Practice 140-47 (June 1971). See also Kansas State Bd. of Healing Arts v. Foote, $200 \mathrm{Kan} .477,436$ P.2d 828 (1968) (court sustained board's revocation of medical license for incompetence even though statute did not state incompetence as grounds for revocation).

75. Derbyshire, What Should the Profession Do About the Incompetent Physician?, 194 J.A.M.A. 119 (1965), discussed in Derbyshire, supra note 74, at 140.

76. Derbyshire, supra note 74 , at 141 .

77. Derbyshire, supra note 72 , at 61.

78. $I d$. 
range from three to five percent. ${ }^{79}$ Thus, the current system disciplines one thirtieth to one fiftieth of the incompetent physicians. ${ }^{80}$ Clearly, all disciplinary systems, including the malpractice system, have not been very effective in dealing with the problem of incompetent practice.

There is little hope that the malpractice system will contribute to a solution of this important problem. Even if licensure boards were to conduct routine reviews of those doctors who lost malpractice claims, the use of this information as a screening device for imstituting disciplinary actions would be very imefficient and possibly misleading, since ever greater numbers of physicians are being sued. Eventually, the state licensure board might be reviewing virtually all physicians. Furthermore, the social stigma of being sued will decrease as the percentage of doctors being sued increases. Finally, in the absence of other information concerning a physician's practice, analysis of malpractice claims is unlikely to be a useful mechanism through which physicians could be disciplined. This function should be part of a quality assurance system which will generate extensive data about the nature and quality of a physician's practice. The addition of information about malpractice claims to these data would be redundant. In any event, the crucial issue is not the collection of data, but whether the quality assurance system will use that data to improve care or, if necessary, discipline physicians.

\section{The Effect of the Malpractice System on the Doctor-Patient Relation- ship}

Most of the arguments that relate changes in the current malpractice system to changes in the level of quality provided focus on alterimg the doctor-patient relationship. Alterations which have been postulated to occur are: (1) increased responsibility of the health care provider for assurance of adequate patient outcomes; (2) performance of more laboratory procedures and tests to verify or correct clinical judgments; (3) discouragement of the use of innovative procedures;

79. Nelson, Incompetent Doctors: Few Lose License, L.A. Times, July 21, 1975, at 1 , col. 1. A recent study indicated that six percent of the physicians who were treating Medicaid patients in New Mexico gave forty percent of the injections judged to be medically inappropriate. R. BROoK \& K. WirliaMs, supra note 32.

80. If three percent of physicians are incompetent and only 0.1 percent are disciplined, then a simple division yields the result that 3.3 percent, or one thirtieth, of incompetent physicians actually are disciplined. With the five percent estimate of incompetence as the divisor, the same division yields a result of two percent, or one fiftieth. 
(4) increased use of consultants; (5) discouragement of the delegation of responsibility, for instance to physician assistants; (6) a raised level of caution inanifested by increased medical recordkeeping; and (7) development of a suspicious and adversary environment between patient and doctor.

That each of these statements is value-laden is obvious. Virtually, all the positive statements could be written in a negative formulation and vice versa. Both facts and an explicit value systern are needed if an adequate understanding of the impact of malpractice on the doctor-patient relationship is to occur. Unfortunately, there is a dearth of information available on the subject. ${ }^{81}$

The central features of many of the poimts raised above involve the notion of defensive medicine. Modern medical science has produced an ever increasing number of costly procedures and tests which can in some cases supply vital medical information and are for the most part harmless. A skull X-ray series for a child with a possible head injury is an example. The issue at hand is whether these tests are performed to protect against malpractice suits or to benefit the patient. Some data suggest that virually no procedures are done to protect against inalpractice, ${ }^{82}$ but former Secretary of Health, Education and Welfare Caspar Weinberger has stated that $\$ 3$ to $\$ 7$ billion may be spent on defensive medicine which is of no benefit to the patient. ${ }^{83}$ An adequate answer to this question will depend on knowledge of the sensitivity and specificity of the tests or procedures being considered and on the value the public places on correct diagnosis or identification of all conditions or diseases. In any event, any further significant jumps in malpractice premium levels may well render previous research and interpretations irrelevant, because the situation in that circumstance would simply not be comparable to the present. It seems reasonable to predict that so-called defensive medicime may indeed rise as a consequence of additional increases in inalpractice premiums of the magnitude of increases to date.

Use of Tests, Procedures, and Consultants. Consider, for instance, a cancer screening test. Assume that the prevalence of the cancer in the population is one in a hundred, the sensitivity of the test (the ability of a test to detect a disease if it is present), is 0.99 , and the specificity of the test (the ability of a test to determine that the person does not have the disease given that the disease is absent) is

81. See Bernzweig, Defensive Medicine, in Medical Malpractice Report Appendix 38.

82. Id. at 39-40; Project, The Medical Malpractice Threat: A Study of Defensive Medicine, 1971 Duke L.J. 939.

83. Weinberger, Malpractice-A National View, 32 ARIz. MED. 117 (1975). 
also $0.99 .^{84}$

The following table indicates what would happen if the screening test were apphied to 10,000 people:

Test Result

Disease present

Disease absent

Total
True Result

Disease Present Disease Absent

Total

$$
\begin{gathered}
\text { Sensitivity }=a /(a+c)=a / 100=0.99 \\
a=99 ; c=1 \\
\text { Specificity }=d /(b+d)=d / 9900=0.99 \\
b=99 ; d=9801
\end{gathered}
$$

For every person who actually has the disease (cell a above), an additional "victim" would be identified, who does not have the disease (cell b); that is, one true positive would be identified for each false positive. One person who actually has the disease would be missed (cell c). If it were desirable to identify every person who has the disease, then the 9802 people in whoin the disease was declared absent must be rescreened. The prevalence of the disease in this smaller population is $1 / 9802$ or 0.0001 ; the results of the rescreening are as follows:

$$
\begin{aligned}
& \text { Test Result } \\
& \text { True Result } \\
& \text { Disease Present Disease Absent } \\
& a+c=1 \quad b+d=9801 \quad 9802
\end{aligned}
$$

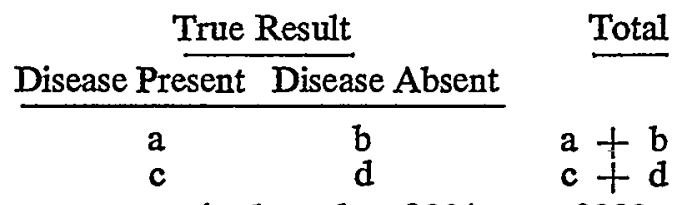

Applying the test to this population twice would result in the identification of 100 true positives, zero false negatives, and 197 false positives. In order to decide whether the second application of this test to a population is worth the cost, society inust place a value on the desirability of detecting every patient with the disease; the value of the harm done to patients falsely labeled as positive inust be compared to the good done to those labeled as true positives. Pliysicians, regardless of the "inalpractice crisis," are trained to err on the side of aggressive management of patients; in the face of uncertainty, they prefer to act,

84. The three statistics chosen represent a very favorable screening situation. Virtually all tests are neither so specific nor sensitive; prevalence of the disease is usually on the order of one in a thousand. 
not to wait. Determination of whether this represents "good" or "bad" defensive medicme must await a value judgment by society. Without an explicit value judgment, some people will argue that dual application of the liypothesized screening test is evidence of the harmful effects of the malpractice issue on quality of care, and other observers will take the opposite view. ${ }^{85}$

The malpractice situation is even more complex than that illustrated by the application of a no-risk screening test to the population. Modern therapeutics have produced potent medicines and procedures (e.g., certain cancer chemotherapies, bone marrow transplants) which may, at great monetary cost, extend the life of a few while producing little benefit to many. How should these therapies be applied? If they are not considered by a physician, is a malpractice claim justified? If they are used and produce harm in some patients, as they certainly must, is a malpractice claim justified? Unless society develops an explicit systein to address these questions, value judgments concerning the relationship between malpractice and the level of quality of care delivered will be difficult to make in the future.

In the past few years, plrysicians have begun to set process criteria which describe what they should do to the patient in order to deliver good care. When these criteria have been applied to actual medical practice, the number of procedures performed (imcluding $\mathrm{X}$-rays) appears to be inadequate by a factor of two or three. ${ }^{86}$ From the viewpoimt of the malpractice issue, no evidence supports the contention that procedures which otherwise have no social value are performed simply for the sake of avoiding malpractice suits. On the other liand, evidence to support the notion that the threat of malpractice litigation increases the performance of useful procedures is also absent, at least in part because changes in physician behavior are difficult to accomplish and require concerted effort. ${ }^{87}$ Substantial improvements in physician behavior are certainly not produced by the threat of malpractice sanctions; otherwise major deficiencies in medical practice would not continue to be identified in quality-of-care studies.

Medical Recordkeeping. Some observers have suggested that the threat of malpractice suits has led to imcreased medical recordkeeping

85. The system-wide consequences of defensive medicine should not be too easily dismissed, especially as they relate to higher costs, patient well-being, misallocation of funds or manpower, and general system performance in the face of scarce resources. Research is needed to address these issues within today's malpractice environment, if realistic appraisals and predictions are desired about the situation tomorrow.

86. See B. Payne \& T. Lyons, Office Care Study, supra note 28; B. Payne \& T. LYONS, EPISODE OF IILNESS STUDY, supra note 28.

87. See Williamson, Alexander \& Miller, Continuing Education and Patient Care Researcli: Physician Response to Screening Test Results, 201 J.A.M.A. 938, 942 (1967). 
and thereby to a better quality of care. ${ }^{88}$ No studies have been performed to support this opinion. Clearly the value of greater recordkeeping is related to the use of this information in future patient management. Recording information just as a protection for court proceedings is a waste of expensive physician time. Unfortunately, the threshold beyond which recording findings becomes wasted effort is unknown. Moreover, evidence suggests that the critical element in medical care delivery may be the reliability with which a history is taken and physical findings are elicited; ${ }^{89}$ the recording of information then becoines of secondary importance.

A definitive answer to whether the malpractice system leads to better quality of care by way of imcreased recording of medical information must await studies which determine the value of this additional information. The results of these studies probably will imdicate that detailed recording of information produces hittle patient benefit. Thus, this malpractice effect will be one of decreasing slightly the efficiency of the medical care system.

Traditional Doctor-Patient Relationship. Fimally, it is asserted that the inalpractice situation is aggravating the dissolution of the "traditional" doctor-patient relationship. Again, in the absence of data to test this assertion, one can only argue that all institutions of society are in a state of decay-whether they be marriage, the family, or government. The times suggest that, even in the absence of the the malpractice crisis, the conventional doctor-patient relationship (authority figure versus dependent figure) would be deteriorating; in the future, the status of the patient and the physician may be more nearly equal. Disappearance of the conventional doctor-patient relationship, whether or not aggravated by the malpractice crisis, may be a social good which will lead to a greater willingness by the patient to assume more responsibility for his own liealth.

In summary, there is hittle information available to answer the question of the effect of the current or future malpractice system on the quality of medical care. Furthermore, even if such information were available, its interpretation would be impossible until society determines what amount of health it wants at what price. In the absence of such information, rhetoric which supports either side of the issue will be heavy, but its impact on policy, one hopes, will be minimal.

88. Roemer, Controlling and Promoting Quality in Medical Care, 35 LAW \& CONTEMP. PROB. 284, 297 (1970). But cf. Lyons \& Payne, The Relationship of Physician' Medical Recording Performance to Their Medical Care Performance, 12 MED. CARE 463 (1974); R. BrooK \& A. AVERY, supra note 42, at 27.

89. Koran, The Reliability of Clinical Methods, Data and Judgments (pts. 1-2) 293 NEW ENG. J. MED. 642, 695 (1975). 


\section{POLICY AND RESEARCH IMPLICATIONS}

The discussion above is characterized by a marked lack of data. Indeed, any relationship between the malpractice crisis and deterioration or improvement in quality of care is established mainly through inappropriate generalization from sparse data and deductive reasoning, except insofar as malpractice is a crystal-clear reflection of poor quality of care in general. The impact of the threat of a malpractice claim on improving the level of quality of care appears to be miniscule when compared to the impact of other factors in the medical care system which dictate the level of quality of care provided. Similarly, no evidence substantiates the assertion that the threat of a malpractice claim seriously impairs the level of patient care provided. The immediate conclusion, then, is that in resolving the malpractice crisis of the 1970s, considerations other than quality should be given a much heavier weight.

Nevertheless, some tentative conclusions can be advanced which permit suggestions for research studies and policy to be made. First, the issue of sanctioning the physician should be separated from that of compensating the patient. A fair system for compensating the patient must be developed, whether that be through a no-fault insurance system, ${ }^{00}$ an arbitration mechanism, or through some form of life or disability insurance. Second, separation of physician sanction from patient compensation should be done carefully, so that resolution of the first issue does not lead to a distortion of the quality of care provided. Third, the opportunity that the present inalpractice crisis provides for increasing the accountability of the inedical care system, especially physicians and hospitals, should not be squandered; physician insistence on having the government involved in solving a medical care delivery problein is not likely to occur again in the near future. ${ }^{91}$ Unfortunately, early attenipts by state legislatures and the federal government to solve the malpractice crisis may lave worsened the quality-of-care probleın. ${ }^{92}$

90. For discussions of the feasibility of nonfault compensation systems for medical accidents, compare O'Connell, No-Fault Insurance for Injuries Arising from Medical Treatment: A Proposal for Elective Coverage, 24 EMORY L.J. 21 (1975), with Keeton, Compensation for Medical Accidents, 121 U. PA. L. Rev. 590 (1973).

91. It should be recognized that this Article addresses a rather narrow issue with respect to malpractice, namely the performance and accountability of physicians. This emphasis should be placed in context, however, and acknowledgement made of the need for other parties to be held equally accountable in the malpractice environment. The quality assurance movement is a viable force in medicine today, and a variety of peer review mechanisms have been established throughout the country; the time is here for the legal profession, the insurance industry, and other principals (e.g., politicians) of the malpractice issue to bring the same discipline to bear on their own activities.

92. Early legislation duplicates various activities of PSROs and of some new bodies 
All but three state legislatures have dealt with the malpractice issue in $1975 .^{93}$ Twenty-eight states have enacted laws; thirty-eight states have established special malpractice study commissions to prepare legislation for 1976 sessions. ${ }^{94}$ An examination of these bills reveals an effort by state legislators to improve the quality of medical care provided as they modify the malpractice system in favor of the physician by, for example, decreasing physician hability or limiting the award size. Laws in ten states require all malpractice claims (or, in some cases, awards and settlements) to be reported to appropriate state boards, the msurance committee, or the legislature. ${ }^{95}$ Michigan, ${ }^{96}$ Ohio, ${ }^{97}$ Nevada, $^{98}$ Florida, ${ }^{99}$ and Oregon ${ }^{100}$ have enacted legislation which requires health care providers, screening panels, medical societies, and hospital review committees to report instances of possible malpractice, questionable professional conduct, or professional imcompetence to the state licensing board. This requirement is intended to precipitate an investigation when reports of sufficient urgency or num-

created at the state level. This will undoubtedly lead to jurisdictional confusion, with overlapping of responsibility in some areas and neglect of tasks in others. To promote the highest possible care, a more streamlined approach is clearly needed, implying a consolidation of efforts at one level or another.

93. According to a survey conducted by Rudolf $L$. Brutoco, one of the authors of this Article, in 1975, the three states which had not taken some legislative steps in the medical malpractice area were Virginia, Wyoming, and Mississippi.

94. See Table I. For a general discussion of the state legislative response to the current malpractice crisis, see Cominent, An Analysis of State Legislative Responses to the Medical Malpractice Crisis, 1975 DUKE L.J. 1417.

95. Act of Mar. 3, 1975, Act 306, § 1, [1975] Ark. Gen. Acts; Medical Injury Counpensation Reform Act, § 2.3, [1975] West's Cal. Legis. Service No. 9, at 3771, 3775-78 (codified at CAL. Bus. \& PROF. Code $\S \S 801$ (a), 802, 803, 805); Medical Malpractice Reform Act of 1975, ch. 75-9, \& 5, [1975] West's Fla. Sess. Law Service No. 1, at 7, 10-11 (codified at Fla. Stat. ANN. \& 768.133(2)); Ind. ANN. Stat. \& 16-9.5-6(1) (Burns Supp. 1975); Ch. 241, [April 9, 1975] Kan. Sess. Laws 647-48; Pub. Act No. 44, \$ 1, [1975] West's Mich. Legis. Service No. 1, at 95, $95-96$ (codified at MicH. CoMP. ANN. \& 500.2477); Ch. 302, \& 6, [1975] Nev. Stat. (codified at Nev. Rev. StaT., tit. 3 (1973)); Act of May 21, 1975, ch. 109, § 2, [1975] McKinney's Sess. Law Service of N.Y. No. 4, at 134, 135 (codified at N.Y. INs. Law $\$ 335$ ); Act of Sept. 13, 1975, ch. 796, § 10, [1975] Ore. Laws (codified at ORE. Rev. Stat. \$ 743); Health Care Services Malpractice Act, Act 111, §§ 401, 702(c), [1975] Purdon's Pa. Legis. Service No. 2, at 296, 299, 303 (codified at Pa. Stat. ANN. tit. 40, $\$ \$ 1301.401,1301.702$ (c)).

96. Pub. Act No. 106, § 1, [1975] West's Mich. Legis. Service No. 3, at 196 (codified at Mich. CoMp. LAws ANN. $\S 338.109 a$ ) (osteopaths); Pub. Act No. 107, $\S 11$ a, [1975] West's Mich. Legis. Service No. 3, at 197 (codified at MicH. CoMP. Laws ANN. \$ 338.1811a) (physicians); Pub. Act No. 111, \& 12(4), [1975] West's Mich. Legis. Service No. 3, at 220 (codified at Mich. CoMP. LAws ANN. $\$ 331.442$ ) (hospitals).

97. Act of July 28, 1975, [1975] Page's Legis. Bull. No. 3, at 174, 182 (codified at OHIO REV. CODE ANN. $\$ 4731.22(\mathrm{C})(2))$.

98. Ch. 303, § 9(1), [1975] Nev. Stat. (codified at Nev. Rev. Stat. $\$ 630.9(1)$ ).

99. Medical Malpractice Reform Act of 1975, ch. 75-9, \& 12, [1975] West's Fla.

Sess. Law Service No. 1, at 15 (codified at FLA. StaT. ANN. $\$ 458.1201(1)(p)$ ).

100. Ch. 796, \& 6(2), [1975] Ore. Laws (codified at ORE. Rev. STAT. \& 677). 
ber about one health care provider are received. (Indeed, some states, e.g., Massachusetts, ${ }^{101}$ statutorily require that all "complaints relating to the proper practice of medicine" be investigated.) Such communications are confidential and individuals making these reports are protected by law from liability, as are members of the review committee. Patient grievance mechanisms also are being implemented in some states. Colorado, for instance, requires an imvestigation of any sworn complaint for reasonable cause. ${ }^{102}$ Eleven states have substantially broadened the basis for disciplinary actions by including substandard or incompetent care as sufficient cause for disciplining a physician. ${ }^{103}$

The range of disciplinary actions available to state licensure boards has also been increased. Previously, probation, suspension, and revocation of license were the basic means of punishment. Certain state boards can now fine a health care provider, require specific additional schooling, issue public reprimands, or restrict a provider's practice to specified areas of competency (e.g., a practitioner could be prohibited from performing surgery or specific surgical procedures). ${ }^{104}$ The availability of these less drastic disciplinary measures is important because the existence of only relatively severe sanctions lias led to the tendency to take no action at all except in the nost extreme cases. Oregon has empowered the Board of Medical Examiners to suspend

101. Act of June 19, 1975, ch. 362, § 3, [1975] Adv. Legis. Service No. 5, at 316 (codified at MAss. ANN. LAws ch. 112, \$5).

102. H.B. $1557, \& 2$ (Colo. 1975).

103. Medical Injury Compensation Reform Act, $\S 16$, [1975] West's Cal. Legis. Service No. 9, at 3786 (codified at CAL. Bus. \& PRoF. CODE $\S 2361$ (c)); H.B. 252, $\$ 1$ (Colo. 1975); Medical Malpractice Reform Act of 1975, ch. 75-9, § 12; West's Fla. Sess. Law Service No. 1, at 15 (codified at FlA. Stat. ANN. $\$ \$ 458.1201$ (m), (o), (p)); IND. ANN. STaT. § 16-9.5-6(2) (Burns Supp. 1975); Act of June 19, 1975, ch. 362, § 3, [1975] Adv. Legis. Service No. 5, at 316 (codified at Mass. ANN. Laws ch. 112, § 5(c)); Pub. Act No. 143, \$ 1, [1975] West's Mich. Legis. Service No. 3, at 288 (codified at Micr. CoMp. LAws ANN. $\$ 338.1811$ (2)(i)); Ch. 303, § 18, [1975] Nev. Stat. (codified at NEv. Rev. Stat. $\$ 630.030$ ); Act of May 21, 1975, ch. 109, $\S 30,[1975]$ McKinney's Sess. Law Service of N.Y. No. 4, at 154-55 (codified at N.Y. EDuc. LAW § 6509(2)); N.C. GEN. Stat. 90-14(6) (Adv. Legis. Service No. 5, 1975); Act of July 28, 1975, [1975] Page's Legis. Bull. No. 3, at 174, 182 (codified at Omo Rev. Code ANN. § 4731.22(B)(6)); ch. 796, \& 2, [1975] Ore. Laws (codified at ORE. Rev. Stat. $\$ \S 677.190(15)$, (16)).

104. Medical Injury Compensation Reform Act, $\$ 22$, [1975] West's Cal. Legis. Service No. 9, at 3787 (codified at CAL. Bus. \& Prof. CODE $\$ 2372.5$ ); Medical Malpractice Reform Act of 1975, ch. 75-9, § 12, [1975] West's Fla. Sess. Law Service No. 1, at 15 (codified at Fla. Stat. ANN. $\$ 458.1201$ (3)(a)); Act of June 19, 1975, ch. 362, \& 3, [1975] Adv. Legis. Service No. 5, at 316 (codified at MAss. ANN. Laws ch. 112, § 5) (reprimand); Act of July 28, 1975, [1975] Page's Legis. Bull. No. 3, at 174, 181 (codified at Ohro Rev. Code Anv. § 4731.22(B)); ch. 796, \& 3, [1975] Ore. Laws (codified at ORE. Rev. Stat. $\$ 677.205(2)(\mathrm{e})$ ); Health Care Services Malpractice Act, Act No. 111, § 901, [1975] Purdon's Pa. Legis. Service No. 2, at 305-06 (codified at PA. STAT. ANN. tit. 40, § 1301.901). 
the physician's license temporarily without a hearing when permitting the physician to continue to practice medicine would constitute an immediate danger to the public, ${ }^{105}$ thereby preventing in the most extreme case the occurrence of additional injury during the process of formal litigation and hearings. In 1971, New Mexico became the first state to require continuing education and periodic relicensure. ${ }^{106}$ Eight states now require post-hicensure education, ranging from fifteen to fifty hours per year. ${ }^{107}$ Six states have passed laws which require physicians to take a competency examination upon demand by the licensing board. ${ }^{108}$

At the federal level, the Kennedy-Inouye bill ${ }^{109}$ contains several intended quality assurance provisions, including: the establishment of national licensure and relicensure standards; ${ }^{110}$ the requirement of PSRO review of participating physicians,; ${ }^{111}$ the evaluation of practitioners who lose a large number of malpractice claims; ;12 the requireinent of concurring consultation for any elective surgery; ${ }^{113}$ and the

105. Ch. 796, $\$ 3$, [1975] Ore. Laws 250, amending ORE Rev. Stat. $\$ 677.205(3)$.

106. Act of Mar. 24, 1971, ch. 135, \& 1, [1971] N.M. Laws 396 (codified at N.M. StAT. ANN. § 67-5-3(E) (1974)), amending N.M. STAT. ANN. \$ 67-5-3 (1953).

107. Medical Injury Compensation Reform Act, $\S 11$, [1975] West's Cal. Legis. Service No. 9, at 3779-80 (codified at CAL. Bus. \& Prof. Code $\$ 2101.6$ ); Pub. Act No. 79-1136 (H.B. 1964) (Ill. 1975); KaN. Stat. ANN. \& 65-2809 (1972) (education requirement at the discretion of the State Board of Healing Arts); ANN. CoDE MD. \& 43-128(c) (Supp. 1975) (education requirement at the discretion of the State Board of Medical Examiners); Act of June 13, 1975, Pub. Act No. 112, \& 1, [1975] West's Mich. Legis. Service No. 3, at 221 (codified at Mrch. CoMP. Laws ANN. \$ 338.1810(7)); N.M. Stat. ANn. $\$$ 67-5-3(E) (1974); Act of July 28, 1975, [1975] Page's Legis. Bull. No. 3, at 174, 182 (codified at Omo Rev. CoDe ANN. § 4731.281(A)); Act of July 23,1975 , ch. $37, \S 10$, [1975] West's Wis. Legis. Service No. 1, at 41-42, as amended, Act of Oct. 2, 1975, ch. 79, \$ 4, [1975] West's Wis. Legis. Service No. 2 at 434 (codified at Wis. StaT. ANN. $\$ 655.017$ ). Twelve state medical associations and five specialty societies have established continuing education requirements for maintenance of membership. Ruhe, Recent Events of Special Interest to Medical Education, 234 J.A.M.A. 1326, 1327 (1975).

108. Medical Injury Compensation Reform Act, $\$ 22$, [1975] West's Cal. Legis. Service No. 9, at 3787 (codified at CAL. Bus. \& Prof. CoDE $\$ 2372.5(a)$ ) (competency exam after the completion of additional training); Ch. 303, $\$ 20,[1975]$ Nev. Stat. (codified at NEv. REv. Stat. \$ 630.140(2)); N.C. GeN. Stat. 90-14(11) (Adv. Legis. Service No. 5, 1975); Act of July 28, 1975, [1975] Page's Legis. Bull. No. 3, at 174, 182 (codified at OHIo Rev. Code ANN. \$ 4731.22(B)(16)); Act of Sept. 13, 1975, ch. 796, \& 7, [1975] Ore. Laws (codified at ORE. Rev. STaT. \& 677. -); Act of Apr. 5,1975 , ch. 61, $\$ 3(2)$, [1975] Wash. Legis. Service No. 1, at 84 (codified at WASH. REv. CODE ANN. \& 18.72.275). The competency exammations in California, Nevada, North Carolina, and Oregon test a doctor's medical knowledge and skills; those in Ohio and Washington examine his inental and physical competence to practice medicine.

109. S. 215, 94th Cong., 1st Sess. (1975) (National Medical Injury Compensation Insurance Act of 1975).

110. Id. \& 1731.

111. Id. § 1725 .

112. Id. § 1707(b).

113. Id. $\S 1704(\mathrm{c})(3)$. 
establishment of provider responsibility for informing patients of adverse results, on the threat of personal liability. ${ }^{114}$

This survey of the law's which liave been passed or are pending in state legislatures and the Congress produced the expected results. Empliasis is on reporting instances of incompetency, continuing education and relicensure, and broadening the effectiveness of state licensure boards. In many ways these legislative actions foster a pieceineal approacli to quality assurance. In part they duplicate the activities of the PSRO and PEP and, except for the Kennedy-Inouye proposals, do little to strengthen them. Relicensure and educational activities will improve care only if deficiency in cognitive knowledge is the major problem in the delivery of better health care. If a pliysician's liabits and behavior, such as his willingness to see a patient in the middle of the night, are more important in determining quality than attending courses, the impact of the relicensure procedures on quality is likely to be severely limited. Mandatory continuing education, which usually contains material of inore interest to the educator than to the practicing plysician, and relicensure requirements inay lead to the mastery of material which is not relevant to the practicing physician or is quickly forgotten. ${ }^{115}$

Tabulation and reporting of the number of pliysician-specific malpractice events are also not likely to improve the quality of medical care. In the absence of knowledge about the plyysician's case mix or the number of patients lie treats, the plysician malpractice claim rate will be virtually useless. Substantial time and money would be spent in investigating such incidents, and this expenditure of resources would likely duplicate the work being performed by whatever quality assurance system exists in the area, such as PSRO. If inalpractice claims must be reported, they slould be reported directly to the PSRO, where the data at least would be concentrated in the liands of one organization which could then generate physician profiles. ${ }^{116}$ These profiles would be used to determine if the malpractice incident is an aberration or represents a typical pattern of practice.

One state bill ${ }^{117}$ and several federal bills ${ }^{118}$ propose the establish-

114. Id. $\S \S 1705$ (c) (1)-(2).

115. See Brown \& Uhl, Mandatory Continuing Education: Sense or Nonsense, 213 J.A.M.A. 1660, 1661, 1667 (1970).

116. The PSRO would know the number of patient care activities of each physician.

117. S.B. 2873 (Wash. 1975). Other proposals, e.g., A.B. 926 (Cal. 1975); H.B. 3251 (Ore. 1975), would have established administrative mechanisms for compensating the victims of iatrogenic injuries, but would have retained neghigeuce as the determinant of provider liability.

118. See, e.g., S. 215, 94th Cong., 1st Sess. (1975); H.R. 4881, 94th Cong., 1st Sess. (1975); H.R. 5183, 94th Cong., 1st Sess. (1975). 
ment of a no-fault imsurance system. The system would identify events that more often than not are due to physician negligence and would compensate patients who have suffered these events without their having to prove physician negligence. A record would be kept of the number of physician-specific compensated events, and this record could be used as a quality-of-care measure. Again the utility of this measure is limited without the simultaneous collection of data which describe the physician's patient care activities. ${ }^{119}$

\section{Research Opportunities}

It would have been desirable to have more information to support the conclusions stated above. Even at this late date in the pohicy debate over malpractice, it would be useful to conduct studies to determine, in a more precise manner, the relationship between malpractice and quality of care. Basic epidemiologic information about the incidence and prevalence of poor physician practice and how it relates to physician characteristics is sorely needed. Studies determining the impact of a large malpractice claim on the patterns of practice in an area could easily be done. For instance, emergency care provided to injury victims could be studied in selected sites. Within a couple of years, at least one large malpractice suit would probably occur in one or more of these sites. Following such a suit, the quality of emergency care could be reassessed to determine the effects, if any, of the malpractice suit. Similarly, studies could be designed which would examine the change in physicians' practices when they move from a high-malpractice situation to a low-malpractice situation, or vice versa. For example, what changes occur when doctors leave military practice where the malpractice claim rate is low and enter the fee-for-service system where it is high? What happens when doctors move either into or out of a prepaid group practice which has a low level of malpractice claims, or into or out of the fee-for-service system which has a higher level of malpractice claims? Finally, perhaps the most important question on which research is desperately needed imvolves the relationship between the commission of events which would be legally compensable vis-à-vis the general level of quality of care that a provider

119. The no-fault insurance system could produce one major paradoxical effect as the definition of a compensable event is broadened. Suppose a patient with terminal cancer seeks treatment from a physician. If this patient died from his disease, his family would not be compensated. If, however, he were treated with powerful drugs which perhaps could be beneficial but were not in this case, and this treatment regimen produced or hastened death, then the patient has suffered a compensable event and his family would be awarded restitution. Since the future economic stability of the family is considered by many physicians when decisions about the care to be given to a terminal patient are made, the pressure would be on the physician to make some deaths that would occur anyway appear to be compensable events. 
renders. Research which answers these questions could greatly facilitate the development of a system for compensating patients which would both provide justice to the patients who have suffered untoward events and increase the level of quality of care rendered to all patients, even those who have not suffered untoward events.

\section{Concluding Remarks}

Up to this point, the conclusions reached are of little use to policymakers. They suggest that nnore research is needed and that proposed changes in the inalpractice system which would include relicensure and mandatory education are likely to be expensive and produce little alteration in the quality of medical care. What then should be done to take advantage of the current crisis and increase the accountability of the inedical care system?

The answer lies in trading off improvements in the entire approach to medical malpractice protection ${ }^{120}$ with fundamental alterations of the current quality assurance system in the United States, the PSRO. When the law containing PSRO was passed, inany compromises were necessary in order to gain some cooperation by the nredical profession. ${ }^{121}$ These compromises nake the PSRO system both less public and less accountable than it could be. Furthermore, they limit the depth and breadth of the quality assessinent activities that the PSRO is permitted to perform. In place of building an expensive duphicate quality assurance system based on reporting nualpractice claims or on relicensure, the current PSRO quality assurance system should be made more accountable by altering it in the following ways:

1. Local PSROs should have elected public inembers, and these public meinbers should observe, if not participate in, the technical review of quality of care; without such public participation bad care can too easily be hidden. ${ }^{122}$

2. The authority of PSROs should be extended to include the review of care given to all patients whether or not their care is financed by the federal government; Medicaid and Medicare patients should not be the only ones to benefit from a quality assurance prograin.

120. To reiterate, these improvements could take the form of significantly lower malpractice premiums (however accomplished), medical panel arbitration of claims, ceilings on physicians' liability (with optional patient self-coverage for higher amounts), or some combination of the above.

121. See 3 U.S. Code Cong. \& Ad. News 4989 (1972); Staff of Senate Comm. On Finance, 93d Cong., 2d Sess., Background Material Relating To Professional Standards Review Organtzattons (PSRO's) (Comm. Print 1974); cf. Gosfield, Consumer Accountability in PSROs, 6 U. TOLEDo L. REV. 764, 770-75 (1975).

122. See Gosfield, supra note 121, at 798. 
3. The authority of PSROs should be extended to cover the review of ambulatory as well as hospital care.

4. The results of the quality audits should be made available to the public by PSRO area, hospital, and if necessary, by physician or at least by a plyysician clraracteristic-such as age or board certification status. ${ }^{123}$

5. Standards and criteria of care should be set nationally instead of locally; otherwise Americans in different medical care areas will be receiving different levels of care.

6. Licensed physicians should be required to participate actively and without compensation in the peer review activities of the PSRO; otherwise their license should be revoked. ${ }^{124}$

7. The effectiveness of the PSRO in altering the quality of care in its community should be determined by means of an external audit prepared by an agency such as the National Center for Health Statistics of the Department of Health, Education and Welfare; without such an audit the validity of the PSRO's results cannot be substantiated.

8. The PSRO should be given the authority to revoke the license of a pliysician. ${ }^{125}$

In the long run, improving the quality of care depends on increasing the public awareness of the medical care system and of what is required to maintain one's lealth. This will necessitate access to information which to date has renuained hidden fron public view. If the present malpractice crisis produces legislation which alters the PSRO system to accomplish these objectives, that outcome will go a long way toward improving the quality of care delivered and thus the liealth of the American people. ${ }^{126}$ Unfortunately these rather sweeping alterations in the PSRO prograin by themselves niay not increase the health of the American people, unless the public dernonstrates its interest in improving its lealth by vigorously monitoring the program through its elected representatives.

123. See id. at 775-89. This suggestion assumes that such analyses would be placed in proper context, so that hospitals or physicians caring for more acutely ill patients are not penalized.

124. Of course, physician time will not be without cost as perceived by the medical care system. It is imperative that physician time for peer review not be considered a "reimbursable" professional activity, but rather a professional responsibility akin to attending graud rounds or keeping abreast of the medical literature.

125. For a detailed description of current quality assurance activities in the United States, see R. Brook \& A. AVERY, supra note 42.

126. For the argument that the development of PSROs will make the malpractice suit superfluous as a quality control device, see Simmons \& Ball, PSRO and the Dissolution of the Malpractice Suit, 6 U. TOLEDO L. REv. 739 (1975). 
Table

November 1975

SELECTED CHARACTIERISTICS OF STATE AND FEDERAL
MALPRACTICE BILIS WIHICH RELATE TO QUALITY OF CARE

Characteristic $^{a, b}$

$\underline{\text { State }}$

Alabama

$\begin{array}{llllllllll}1 & 2 & 3 & 4 & 5 & 6 & 7 & 8 & 9 & 10\end{array}$

Alaska

Arizona

Arkansas

California

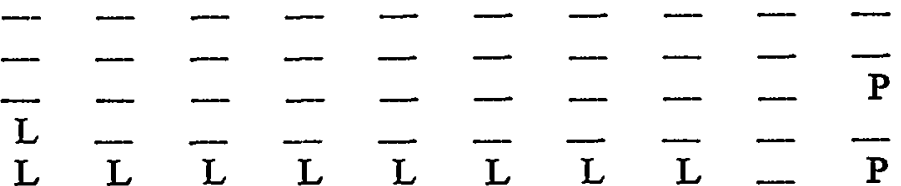

Colorado

Connecticut

District of

Columbia

Delaware

Florida

Georgia

Hawaii

Idaho

Illinois

Indiana

Iowa

Kansas

Kentucky

Louisiana

Maine

Maryland

Massachusetts Michigan

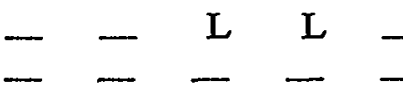

a Action in 1975: $P=$ Proposed

$\mathrm{L}=$ Enacted into Law

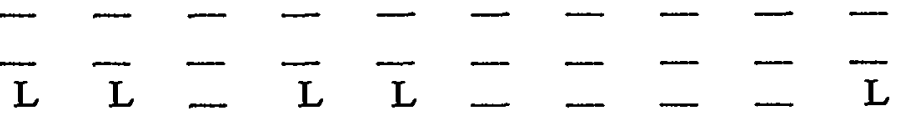

$\bar{E} \overline{\mathrm{P}} \overline{ \pm} \overline{ \pm} \overline{ \pm} \overline{ \pm} \overline{ \pm} \overline{\mathrm{L}}$
$\overline{\mathrm{L}}$

$------\ldots-\mathrm{L}$

$\mathrm{L}---\mathrm{E} \mathrm{E}-$

$= \pm \equiv \pm \equiv \pm \bar{L}$

$\mathrm{E}=$ Existing bLegend

1. Requires all malpractice claims and/or settlements to be reported to governmental agency

2. Requires reporting of repeated or gross malpractice and/or professional incompetence and/or disciplinary actions to State Board by screening panels, medical societies, or hospital review commitlees

3. Quality assurance boards established, or state licensing boards charged with increased responsibility for on-going monitoring of provider performance

4. Broadens basis for disciplinary action against liealth care providers

5. Provides for restriction of praclitioners' license

6. Provides for competency examinations for continued licensure at State's discretion

7. Periodic relicensure

8. Requires continuing education

9. Requires PSRO review of services of participating providers

10. Specifies crileria for informed consent 


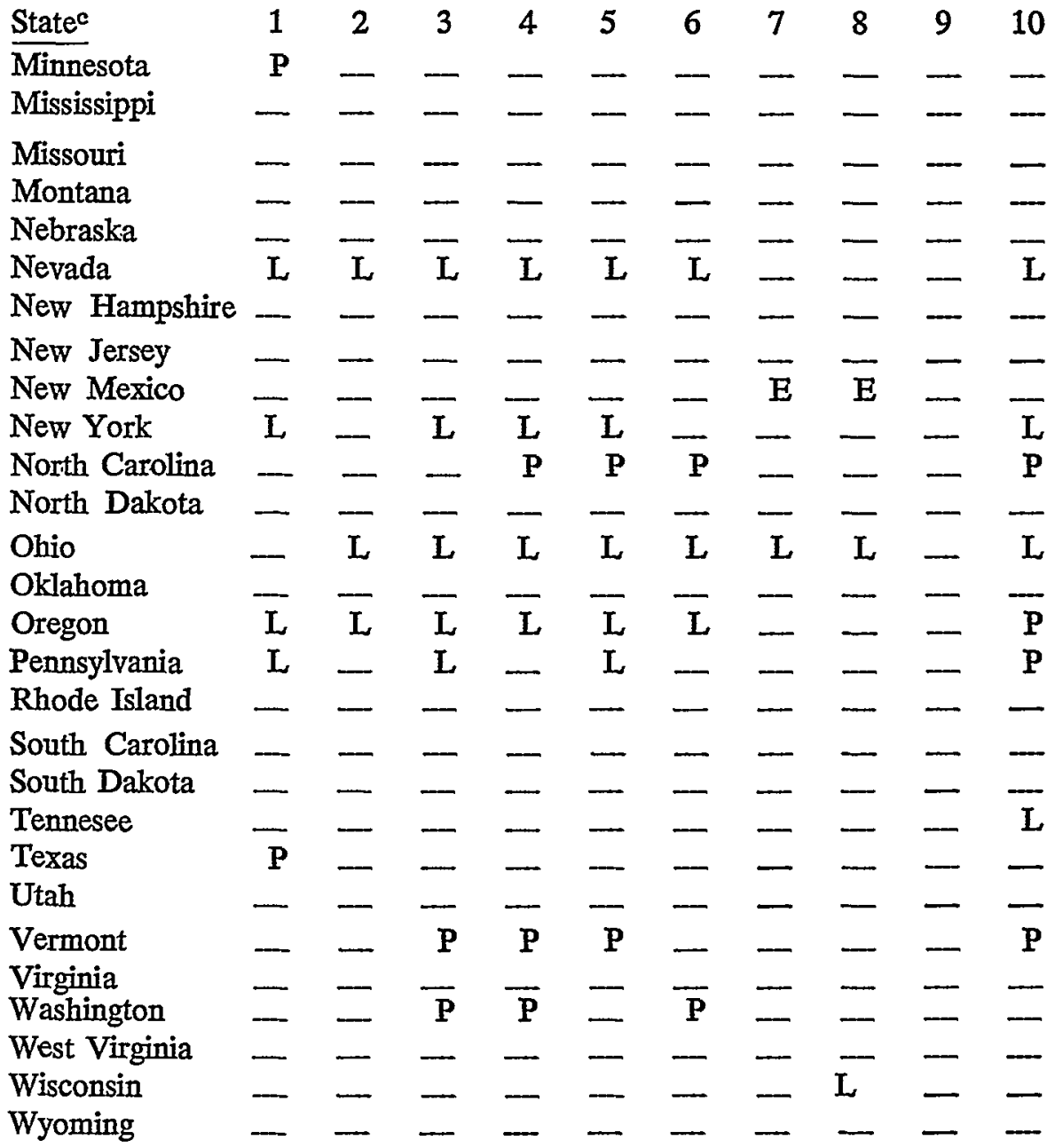

Federal

S. 215

S. 432

S. 188

HR 1600

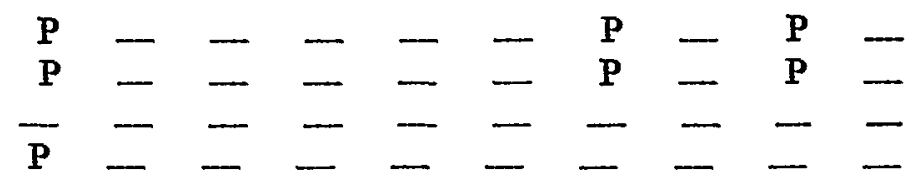

cStatutes enacted or proposed in 1975 in survey: Act of Mar. 3, 1975, Act 306, [1975] Ark. Gen. Acts; H.B. 2418 (Ariz. 1975); Medical Injury Compensation Act, [1975] West's Cal. Legis. Service No. 9, at 3776; CoLo. REv. STAT. ANN. \$\$ 12-36-117 (1) (p) and 12-43.5-101 to 103; FLA. STAT. ANN. $\$ \$ 458,768$ (Supp. 1976); S.B. 1389 (Hawaii 1975); IDAHO Code ch. 41 (Supp. 1975); Pub. Act No. 79-1136 (H.B. 1964) (I11. 1975); IND. ANN. STAT. tit. 16, \& 16-9 et seq. (Burns Supp. 1975); H.F. 803, [1975] Iowa Legis. Service No. 3; Act of Apr. 9, 1975, ch. 241, [1975] Kan. Sess. Laws 647-48; Pub. Act No. 529 (H.B. 636, (La. 1975)); MAss. ANN. Laws ch. 112, \& 5 (Supp. 1976); MicH. CoMP. LAWS ANN. \$\$ 331.422, 338.109, 338.1810 (Supp. 1976); H.F. 1803 (Minn. 1975); Nev. REv. STaT. $\$ \$ 630.003$ et seq. (1975); Act of May 21, 1975 , ch. 109, [1975] McKinney's Sess. Law Service of N.Y. No. 4, at 134; N.C. GEN. StAT. 90-14(6) (Supp 1975); OHIo ReV. Code ANN. \& 4731 et seq. (Page Supp. 1976); ORE. REv. STAT. $\$ \$ 677$ et seq. (Supp. 1976); PA. STAT. ANN. tit. 40, $\$ 1301$ (Supp. 1976); TENN. CODE ANN. $\$ \$ 23-3401$ to 3421 (Supp. 1975); S.B. 635 (Tex. 1975); S. 170, 171 (Vt 1975); WASH. REV. CODE ANN. \$\$18.72 et seq. (Supp. 1976); WIS. Stat. Ann. § 655 (Supp. 1976). 
